\title{
Retningslinjer eller egen erfaring?
}

\author{
Mye medisinsk behandling er basert på erfaring. Denne erfaringen må videreformidles for at den skal komme \\ den medisinske utviklingen til gode.
}

På en WONCA-kongress i Stockholm for 15-16 år siden hørte jeg et innlegg av Per Fugelli om erfaringsbasert kunnskap i medisinen. Han pekte på hvor viktig det var at denne kunnskapen ble formidlet og ikke «døde» med de legene som mente at de hadde erfaring fra praksis som andre kunne ha nytte av.

I allmennmedisinen blir det av og til brukt behandling som ikke følger oppsatte retningslinjer. Resultatene kan synes så gode at man velger å fortsette med slik behandling. Jeg mener å huske at tidlig i 1980-årene var retningslinjene for behandling av urinveisinfeksjoner en ukes antibakteriell terapi. Ved vårt legesenter registrerte vi at kvinner med ukompliserte cystitter ofte sluttet med behandlingen etter et par dager fordi de var symptomfrie. Vi ble derfor enige om å behandle disse bare 1-3 dager. Og var de ofte plaget, fikk de råd om å ha en liten dose Furadantin hjemme og ta en tablett når de fikk symptomer på akutt cystitt. I dag er vel retningslinjene omtrent som det behandlingsregimet vi begynte å bruke for over 30 år siden. Jeg tror ikke det bare var oss som da rådet til slik korttidsbehandling.

\section{Prednisolon som alternativ til ikke-} steroide antiinflammatoriske midler Jeg har vært allmennpraktiker siden 1967 og har i alle disse årene vært spesielt interessert $\mathrm{i}$ idrettsmedisin og plager fra bevegelsesapparatet. I idrettsmedisinen ble det brukt mye ikke-steroide antiinflammatoriske midler etter at disse kom på markedet. Med årene opplevde jeg ofte at de hadde plagsomme bivirkninger og at virkningene på de mer akutte plagene var heller beskjedne. For omtrent 20 år siden begynte jeg å forskrive prednisolon $20 \mathrm{mg}$ daglig i 1-6 dager sammen med paracetamol $1 \mathrm{~g} \times 3$ ved akutte lave ryggsmerter. Erfaringene var så gode at dette ble min måte å behandle pasienter med slike plager på. I tillegg rådet jeg pasientene til å gå tur på grusvei eller i utmark så snart de var i stand til det. Turgåing ved akutte og kroniske ryggplager er imidlertid noe jeg har rådet pasienter til så lenge jeg kan huske. Den gode erfaringen etter prednisolonbehandling er derfor neppe bare et resultat av turgåingen.

Disse korte prednisolonkurene krever ikke gradvis nedtrapping av dosen, og bortsett fra litt rødming en sjelden gang har jeg ikke registrert bivirkninger av betydning. Den minste pakningen på prednisolon $20 \mathrm{mg}$ er 25 tabletter. Jeg har vært nøye med å forklare pasientene at midlet ikke må brukes lenger enn en knapp uke og at dette er medisin som har mange uheldige virkninger ved langvarig bruk.

Samtidig med at jeg begynte å bruke prednisolon ved akutte ryggplager, begynte jeg også å bruke prednisolon $20 \mathrm{mg}$ daglig $i$ inntil en uke ved akutt arthritis urica. Pasienter som ikke hadde så hyppige anfall at det var aktuelt å vurdere profylaktisk behandling, rådet jeg til å ha en liten pak-

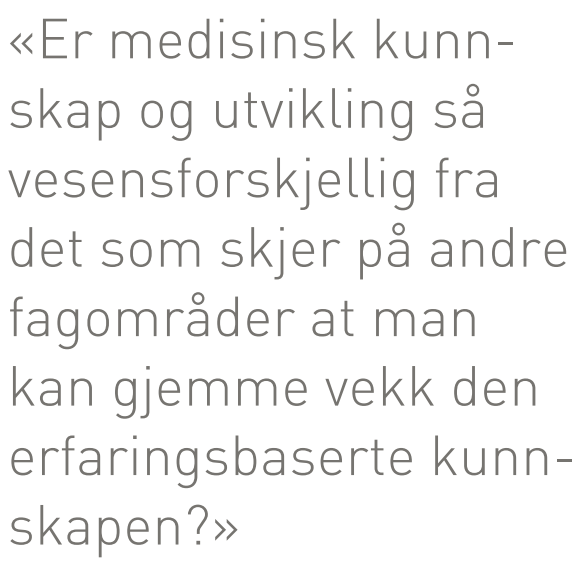

Torbjørn Måseide (f. 1940) er pensjonert kommuneoverlege, helsesjef og fastlege i Ulstein kommune.

Forfatter har fylt ut ICMJE-skjemaet og oppgir ingen interessekonflikter.

Mottatt 20.11.2014 og godkjent 2.12. 2014. Redaktør: Hanne Støre Valeur.

Publisert først på nett.

vesensforskjellig fra det som skjer på andre fagområder at man kan gjemme vekk den erfaringsbaserte kunnskapen, slik det kan se ut som om man gjør i dag? Det bør være
ønskelig for medisinens utvikling at også erfaringsbasert kunnskap får et bredt forum for kommunikasjon!

\section{Torbjørn Måseide}

torbjornm@mimer.no ning prednisolon $20 \mathrm{mg}$ hjemme slik at de kunne starte behandling med det samme de fikk symptomer. Til disse var jeg spesielt nøye med å forklare bivirkningene av prednisolon dersom det ble brukt for ofte og for lenge. I min praksis har dette vært en behandling pasientene har vært svært fornøyd med, og det er blitt standardbehandling for arthritis urica ved vårt legesenter.

\section{Bortgjemte erfaringer}

Medisinsk litteratur er dominert av artikler der vitenskapelig dokumentasjon er sentralt. Kunnskapsbasert praksis er det vi er opptatt av. Som lege i Ulsteinvik siden 1974 har jeg fungert midt $i$ det området som har fått betegnelsen «den maritime klyngen» i Norge. Dette er et område der verft og en underskog av maritime bedrifter med internasjonal orientering har fått stor kompetanse og mye oppmerksomhet. Mye av den verdensledende kompetansen i disse bedriftene er basert på videreutvikling av teknologien etter erfaringer som sjøfolk og redere har fătt ved drift av skipene.

Men slik utvikling skjer bare dersom erfaringene videreformidles til dem som skal gjøre skipene bedre.

Er medisinsk kunnskap og utvikling så 